courses which should be taken by men after a number of years of service. The Colonial Service would in this way be able to continue to share in the benefits of that universal framework for more specialized studies which the universities seek to confer. There should, in view of their traditions of freedom and of devolution of authority, be no serious difficulty in developing, in one or more of the universities of the British Empire, in close association with academic departments including special Colonial studies, training schools which, while providing fully the conditions needed for the desired esprit de corps, would have the advantages of a continuous outlook on wider horizons.

\section{THE PUBLIC LIBRARY IN RECONSTRUCTION}

$\mathrm{T}$

HE importance of the industrial or scientific library as a tool of research and as a service to the investigator or technical man on a par with the material services such as power supply; light and water, which along with his equipment he is apt to take for granted, is now gaining recognition. This interest must now be extended to include the public library service, for an efficient public library service is highly important as a factor in adult education. The public library service, too, must play an important part in education for citizenship, and in that respect scientific workers themselves might well be glad to avail themselves more freely of its services.

These reasons alone would give public library services an important place in reconstruction. The report on "The Public Library System of Great Britain", prepared by Mr. L. R. McColvin, city librarian of Westminster, for the Library Association, demonstrates beyond dispute the need for drastic overhaul and reorganization. This report, however, has also a close bearing on those questions of regionalism and the relation between national and local control which are encountered almost everywhere when plans for post-war development are being considered. The provision of public library services has hitherto been left entirely to the local authorities, and the quality of their performance affords a fair test of their fitness for full responsibility in others.

The Acts of Parliament by virtue of which public libraries exist are permissive, not compulsory. That does not invalidate the fairness of this test of the fitness of the local authorities, but this survey, with its picture of widely varying performance, leaves an outstanding impression of the unsatisfactory general provision and of a badly organized service which reflects sadly on the competence of the local authorities and stamps permissive legislation in this field as a comparative failure. That is indeed the major interest of the survey itself. On points of detail the scientific worker will note the duplications, deficiencies and glaring disparities which abound, the absence of general standards for salaries and the consequence that many library workers are not properly qualified for their posts, understaffing and inadequate premises, parsimonious expenditure on books and indeed every other item, and the pronouncement that reference library work is the outstanding failure of librarianship in Great Britain.

One point in this survey has direct implications for the seientific worker. Mr. McColvin emphasizes the fact that a poor library does not immediately result in a demand for a better one. The public does not normally ask for a better library service unless it already has experience of a good one. It is only a good library that can demonstrate the advantages and uses of a developed service. Mr. McColvin, in fact, points out that several counties and backward municipalities have been, if not compelled to improve, at least made cognizant of their deficiencies, by evacuated readers who have been accustomed to good libraries in their home towns. Similarly, scientific workers who have at least learnt something of the value and possibilities of a library service owe it to their fellow citizens to play their part in securing for the community as a whole a public library service which adequately meets the purposes set forth in this report.

The basic purpose of the public library, in Mr. McColvin's view, is the utilization of the recorded experience and thought of the men and women of yesterday and to-day to help in the making of citizens better able to contribute to, and benefit from, the constructive life of the community, the nation and the world. Much of that accumulated experience is only available in books, and the society which lacks adequate public libraries is accordingly handicapped by the lack of information and knowledge essential to its material, mental and spiritual development. Books, he urges, are essential to any real democratic conditions of living; they are the tools and the symbols of true freedom.

That conception of an efficient, readily accessible and comprehensive library service, hospitable to all phases of thought, as an essential element in a progressive society, will be endorsed everywhere. The execution of the broad programme outlined in this report and the details of its proposals will rightly be held largely a matter for discussion and decision by the professional librarian in the first place, though even at this stage the scientific worker might well support some of the proposals or observations, such as the adoption of a deliberate national policy of linking up and strengthening existing special libraries, so reducing unnecessary duplication, and gradually extending their range. Moreover, some at least of its observations in regard to stock, purchases, premises and methods are as relevant to the specialist or departmental library as to the general or public library, and well deserve to be carefully weighed.

Mr. McColvin's proposals, however, are worth noting for the further reason which is evident even from a brief summary. An efficient library service may well be an important factor in reconstruction; but, in addition, library reform is an excellent example of the technique required in a democracy for the adjustment of its institutions by consent to serve the purposes of an ever-changing society. 
The faults of the present system, on Mr. McColvin's showing, are attributable to the inherent defects of local control. The first task is therefore to create, as the area for each independent local library service, a local unit sufficiently large to facilitate co-ordination and ensure efficiency and economy. These units, of which ninety-two are enumerated, will comprise areas formed for geographical reasons and answering to the distribution of population. Each unit would include an administrative and distributive headquarters with main central library and a radiating system of libraries, branches, distributing centres and travelling library vans, appropriate to the different aggregations of population in the area, the urban and rural services being under a single direction.

Mr. McColvin insists on the management of the unit remaining in local hands and not being placed under the control of the central government or of larger regional authorities. On the other hand, he is emphatic as to the necessity of a central national department responsible for guiding, co-ordinating and encouraging library development, making grants in aid of library services, and supervising their expenditure. He also urges the development of large regional reference libraries assisted by national funds, as well as the fullest possible co-operation between public libraries and all types of other libraries and institutions for research, especially in connexion with specialization and inter-library lending. Efficient management, staffing and an appropriate relation between supply and demand are other points in the proposals.

The National Central Library should be an integral part of the national system and guaranteed a reasonably permanent means of existence and the resources to plan for the future and for whatever developments the national interests might demand. Primarily, it would be a clearing house and centre for the execution of national library projects-cataloguing, bibliography and co-operation. With the development of good library units throughout Great Britain, it should no longer be necessary for the National Central Library to act as a storehouse of reserve stocks, and the units should also decrease the demands on it for work for adult education. Moreover, the removal of the limitations imposed by financial stringency on its present or contemplated work, the supply to library units of specialized books which it is impossible or undesirable for the units to provide themselves, the maintenance of the necessary organization for such inter-lending, the development and maintenance of co-operation between public libraries and others, including the special libraries, its functions as a national centre for bibliographical information, as a central cataloguing department, in organizing international loans and as a centre and clearing house for bibliographical information regarding the literature of other countries, would enable the National Central Library to form the natural keystone of all inter-library co-operation.

With regard to the central authority, Mr. McColvin suggests either a department of a new Ministry of Arts or a Libraries Department of the Board of Education, though he directs attention to the danger of associating a library system too closely with education in the scholastic sense. In addition to the broad duties already indicated, this authority would also be responsible for formulating minimum standards of library service, especially in regard to the supply of books, the availability of services and the qualifications and salaries of those engaged in library work, as well as for the collection of information, conduct of inquiries or issue of reports on the general progress of librarianship and on special aspects thereof. The proposals contemplate an interim period of voluntary reorganization, and the application of compulsion only as a last resource.

It is clear that these proposals touch fundamental issues involved in regionalism and in the re-grouping of local government units. Mr. McColvin recognizes that the civil defence regions of Great Britain may not prove altogether suitable regional units, and that new areas introduced as a result of changes in local government may equally be unsatisfactory and unsuitable for library purposes. He also recognizes that, on the other hand, there may be no considerable reform of local government areas in general for some years. None the less, he urges librarians to place their ideas and ideals at the disposal of all who are concerned with the reconstruction of local government, and to collaborate with them to the fullest possible extent.

In thus urging collaboration and readiness to accept adjustments of the unit system where the adjustments are not such as to prejudice seriously the essential requirements, Mr. McColvin shows the same wisdom and restraint which throughout his report balance his stout defence of the independence and identity of the librarian. It cannot be said of this report, as of some other recent ventures into the field of reconstruction, that the proposals are more concerned to advance the interests of a section than to serve those of the whole community. The fundamental truth that democracy is based on the consent of the governed is firmly upheld throughout.

The report is in fact to be welcomed for its support of those two points, apart altogether from the proposals it advances for reform in a matter which touches closely the mental well-being of the whole nation. It is a stimulus to constructive thinking about some of the issues upon which the existence of our democratic institutions depends. In recognizing the failure of small units, in libràry service as elsewhere, to function efficiently or even effectively, we should not forget that not only may those units have other contributions to offer, but also that it is of the essence of a democracy that their willing consent should be won to participation in the larger units now necessary. Secondly, it should be recognized, as is implicit in this report, that while it is for the expert and professional worker to submit his proposals, and even to execute them when approved, it is for the community to decide on policy.

There is no graver danger to reconstruction than the tendency to be observed in so many reports from the industrial and business world for sections to attempt to dictate policy and for their plea for selfgovernment or freedom from interference to cloak an 
attempt to impose an economic system on the community in preservation of sectional interests. Democratic policy, it is true, must be positive, but danger lies in the plea that such questions as the abolition of unemployment, disease and ignorance should be regarded as technical questions and outside politics. In a parliamentary democracy, it is for the electorate to decide whether it is prepared or not to accept whatever restraints on individualism may be necessary to secure these or other objectives. It is then and then only for the expert to frame and execute, under the supervision of parliament, the measures necessary to give effect to the policy adopted by the electorate. Library service may well seem a small matter among the many problems which are the subject of debate for reconstruction to-day, but in this report 'first things' are laid bare with unhesitating precision.

\section{BIOLOGICAL STATISTICS}

\section{The Reproductive Capacity of Plants}

Studies in Quantitative Biology. By Prof. E. J. Salisbury. Pp. xi $244+7$ plates. (London: G. Bell and Sons, Ltd., 1942.) 30s. net.

$\mathrm{T}$ HOSE who are familiar with Prof. Salisbury's earlier applications of statistical methods to structural characters, presumed adaptive, will approach with lively anticipation this quantitative study of reproductive capacity. In his investigation of stomatal distribution he gave precision to the general observations of Zalenski and others, in particular that in dry conditions leaves tend to have more stomata per unit area, whereas the reverse might have been expected. He further demonstrated that, for a given species, the spacing of the stomata is dependent on the size of the epidermal cells and so on the degree of expansion of the leaf during its development. $\mathrm{He}$ thus contributed weightily to the replacement of the teleological by the causal point of view in the interpretation of such features.

In the present volume he has collected together measurements, accumulated over a period of fifteen years, of the number of fruits and seeds produced by sample populations of a wide range of species of representative habitats, with the object of examining quantitatively the rough impressions and certain teleological assumptions that have gained currency. The amount of labour and patience required in obtaining so impressive a body of data prompts the thought, a chacun son métier.

Among the leading questions propounded is whether the relative abundance and frequency of different species are correlated with their reproductive potentialities. On the other hand, since on the average the number of individuals of different species remains approximately stable, it has been commonly assumed that natural selection has brought about a nice adjustment between seed output and mortality : Is reproductive potentiality in fact proportioned to vulnerability, or is the production of a large progeny rather to be regarded as merely wasteful ?

The complexity of the problems is made apparent from the outset. The author points out, for example, that fluctuation in number of offspring has the effect of countering the danger from predators. Though "mast" years lead ultimately to an increase in number of predators, the inevitable lag enables the sudden abundance to be effective, in increasing the number of individuals, at least temporarily, and possibly securing the spread of the species. Another complicating factor is seed size, which is examined and discussed in Chapter 2. It is established that the more advanced the phase of ecological succession the larger are the seeds, on the average, of the species characterizing the vegetation; and the author points out that the smallest seeds are to be found among plants of open habitats, and also among parasites, saprophytes and mycorrhizal plants, which are not dependent for survival on early photosynthesis.

In Chapter 3 it is shown that parental vigour, estimated by the number of fruits borne, has no significant effect on the viability of the seeds set and very little on their size. Apparently, below a certain minimum of food supply an ovule or seed aborts and the effect of starvation is seen in fewer seeds of nearly normal size.

Having defined his terms, of which the most important is reproductive capacity, the product of the average seed output per plant and the average percentage germination, the author proceeds to examine the data for different edaphic and climatic conditions and the effects of competition. He remarks that competition may sometimes be the more important and gives examples of perennials in which the onset of reproduction is delayed for years by competition. Between individuals of the same species, on the other hand, while competition leads to depauperate individuals, it affects the total output but little whether many small or few large plants survive. In Chapter 7 it is established that no correlation exists between number of capsules per plant and number of seeds per capsule.

The remainder of the book is devoted to a comparative study of reproductive capacity over a wide range of examples. The general conclusion frequently emerges that there is no evidence of reproductive capacity being correlated with risk of mortality, but definite evidence of correlation with extent of geographical range (for example, Scilla spp.) and with relative abundance (for example, Hypericum spp., Gentianaceæ). Vegetative spread and multiplication complicate comparisons and receive special discussion in the concluding chapter.

The discussions of special cases are full of interest and are informed throughout with original observations which add greatly to the value of the book. It will provide a mine of information for contributors to the biological Flora, which is being compiled under the auspices of the British Ecological Society.

To the general reader it may be a matter of regret that the statistical data are given in extenso throughout the text. The summaries and, still more, the many comments and original observations are in consequence more difficult to pick out. While it is desirable that data so laborious of collection should be permanently preserved and accessible, the value of the book would, in the reviewer's opinion, have been increased had the bulk of the data been segre. gated. A limited number of examples would have sufficed to illustrate the chief statistical features and the methods of statistical treatment. The results could then have been given in the text mainly in the form of averages with standard deviations.

A minor point to which attention should perhaps be directed is the author's interpretation of probable error when, having obtained an average $A \pm p$, 